\title{
Movements and dispersal of brown trout (Salmo trutta Linnaeus, 1758) in Mediterranean streams: influence of habitat and biotic factors
}

\author{
Enric Aparicio ${ }^{\text {Corresp., }}{ }^{1}$, Rafel Rocaspana ${ }^{2}$, Adolfo de Sostoa ${ }^{3}$, Antoni Palau-Ibars ${ }^{4}$, Carles Alcaraz ${ }^{5}$ \\ 1 Institute of Aquatic Ecology, University of Girona, Girona, Catalonia, Spain \\ 2 Gesna Estudis Ambientals, Linyola, Catalonia, Spain \\ 3 Department of Animal Biology and Biodiversity Research Institute (IRBIO), University of Barcelona, Barcelona, Catalonia, Spain \\ 4 Department of Environment and Soil Sciences, University of Lleida, Lleida, Catalonia, Spain \\ 5 IRTA Marine and Continental Waters, Sant Carles de la Ràpita, Catalonia, Spain \\ Corresponding Author: Enric Aparicio \\ Email address: enric.aparicio@gmail.com
}

\begin{abstract}
Dispersal is a critical determinant of animal distribution and population
\end{abstract} dynamics, and is essential information for management planning. We studied the movement patterns and the influence of habitat and biotic factors on Mediterranean brown trout (Salmo trutta) by mark-recapture methods in three headwater streams of the Ebro Basin (NE Iberian Peninsula). Fish were sampled by electrofishing on five occasions over 18-24 months and movements of over 3,000 individually tagged trout (age 1+ onwards) were recorded. Most of the tagged fish exhibited limited movement and were recaptured within $100 \mathrm{~m}$ from the initial capture section. Small seasonal differences in the movement pattern were observed, but in two of the streams, displacement distances increased prior the spawning period in autumn. The frequency distributions of dispersal distances were highly leptokurtic and skewed to the right and fitted well to a two-group exponential model, thus trout populations were composed of mobile and stationary individuals, the latter being the predominant component in the populations (71.1-87.5\% of individuals). The mean dispersal distances, for fish captured at least in three sampling events, ranged 20.7 - $45.4 \mathrm{~m}$ for the stationary group and 229.4 - $540.5 \mathrm{~m}$ for the mobile group. Moving brown trout were larger than non-moving individuals and exhibited higher growth rates in two of the streams. Habitat features were not consistently linked to movement rates, but there were some interaction effects between stream and habitat characteristics such as depth, cover and water velocity. 
1

2

$51(\bowtie)$ GRECO, Institute of Aquatic Ecology, University of Girona, E-17071 Girona, Catalonia,

6 Spain. e-mail: enric.aparicio@gmail.com ORCID: 0000-0001-8810-0783

$7 \quad 2$ Gesna Estudis Ambientals, S.L., Linyola, Catalonia, Spain

$8{ }^{3}$ Department of Animal Biology and Biodiversity Research Institute (IRBIO), University of

9 Barcelona, Barcelona, Catalonia, Spain

${ }^{4}$ Department of Environment and Soil Sciences, University of Lleida, Lleida, Catalonia, Spain

$11{ }^{5}$ IRTA Marine and Continental Waters, Carretera Poble Nou Km 5.5, E-43540 Sant Carles de la

12 Ràpita, Catalonia, Spain 


\section{Abstract}

14 Dispersal is a critical determinant of animal distribution and population dynamics, and is

15 essential information for management planning. We studied the movement patterns and the

16 influence of habitat and biotic factors on Mediterranean brown trout (Salmo trutta) by mark-

17 recapture methods in three headwater streams of the Ebro Basin (NE Iberian Peninsula). Fish

18 were sampled by electrofishing on five occasions over 18-24 months and movements of over

193,000 individually tagged trout (age 1+ onwards) were recorded. Most of the tagged fish

20 exhibited limited movement and were recaptured within $100 \mathrm{~m}$ from the initial capture section.

21 Small seasonal differences in the movement pattern were observed, but in two of the streams,

22 displacement distances increased prior the spawning period in autumn. The frequency

23 distributions of dispersal distances were highly leptokurtic and skewed to the right and fitted well

24 to a two-group exponential model, thus trout populations were composed of mobile and

25 stationary individuals, the latter being the predominant component in the populations (71.1 - 87.5

$26 \%$ of individuals). The mean dispersal distances, for fish captured at least in three sampling

27 events, ranged 20.7 - $45.4 \mathrm{~m}$ for the stationary group and $229.4-540.5 \mathrm{~m}$ for the mobile group.

28 Moving brown trout were larger than non-moving individuals and exhibited higher growth rates

29 in two of the streams. Habitat features were not consistently linked to movement rates, but there

30 were some interaction effects between stream and habitat characteristics such as depth, cover and

31 water velocity. 


\section{Introduction}

Dispersal, defined as the movement of individuals between locations, is a key process that

34 allows fish to occupy the most suitable habitat for survival, growth and breeding by adapting to

35 both temporal and spatial changes in environmental or biotic conditions (Railsback et al., 1999;

36 Lucas \& Baras, 2001). Fish movement can be highly variable between individuals, species and

37 streams (Rodríguez, 2002). Most research on fish dispersal in streams shows heterogeneous

38 populations comprising both sedentary and mobile individuals (Rodríguez, 2002; Rasmussen \&

39 Belk, 2017). The movement distribution (i.e. distance moved vs. probability of occurrence) is

40 then best predicted by leptokurtic dispersal models which are characterized by high peaks

41 associated with the sedentary fish, and longer tails associated with a lower proportion of mobile

42 fish (Skalski \& Gilliam, 2000; Rodríguez, 2002). This modelling framework has been applied to

43 describe the general movement patterns of fish and a predictive tool was recently developed

44 based on the positive correlation of movement distances with four variables: fish length, aspect

45 ratio of the caudal fin, stream size, and duration of the study (Radinger \& Wolter, 2014). At a

46 local scale, both abiotic and biotic factors affect the degree of movement, variability and

47 dispersal rates. For instance, some studies have reported an increase in exploratory behaviour

48 (i.e. higher proportions of mobile fish) with decreasing habitat heterogeneity (Albanese,

49 Angermeier \& Dorai-Raj, 2004; Heggenes et al., 2007); the presence of fish cover (e.g. woody

50 debris and boulders) has been related to a reduction in fish movement (Aparicio \& Sostoa, 1999;

51 Harvey, Nakamoto \& White, 1999); and population density has been positively linked to fish

52 movement rates (Hesthagen, 1988).

53 The mobility and dispersal patterns of brown trout Salmo trutta Linnaeus, 1758, have been

54 reported to be largely variable. Some populations are mainly sedentary (Northcote, 1992; Burrell 
55 et al., 2000; Knouft \& Spotila, 2002), while others are dominated by individuals that move

56 extensively (Clapp, Clark Jr \& Diana, 1990; Meyers, Thuemler \& Kornely, 1992; Ovidio et al.,

57 1998). The movement patterns of brown trout have been widely studied within its native range in

58 central and northern Europe, as well as in its introduced range in North America (see Rodríguez,

592002 , and references therein), but the information on brown trout movements in rivers flowing to

60 the Mediterranean Sea, in its southern native range, is scarce. There is only a study in the Rhône

61 River focussed on the movements of age 0+ individuals (Vatland \& Caudron, 2015). Brown trout

62 populations in the Mediterranean Basin are highly genetically differentiated from central and

63 northern Europe populations and are considered as distinct lineages (Bernatchez, 2001; Cortey,

64 Pla \& García-Marín, 2004). These populations have experienced a marked decline in the last

65 decades due to stream habitat degradation (Benejam et al., 2016), overfishing (Almodóvar \&

66 Nicola, 2004), and introgressive hybridization with hatchery stocks (Aparicio et al., 2005).

67 Climate change scenarios for the Mediterranean predict additional reductions in brown trout

68 distributional range, due to rising water temperatures (Almodóvar et al., 2012). Consequently,

69 there is an urgent need to develop sound conservation and management strategies for preserving

70 these populations. With increasing river fragmentation, quantifying the scale and magnitude of

71 Mediterranean brown trout dispersal patterns and determining the factors that drive these, are

72 necessary to optimize management planning.

73 The overall purpose of this study was to examine the movement patterns of brown trout

74 populations from three separate streams of a Mediterranean catchment of the Iberian Peninsula

75 and the influence of biotic and abiotic factors. The three study streams are small, have a high

76 gradient, and considerable habitat heterogeneity. When all habitats required to complete the

77 cycle of a fish's life-history are in spatial proximity, lower movement distances are expected 
78 (Albanese, Angermeier \& Dorai-Raj, 2004). Also, structural habitat complexity increases

79 protection from predators, refuge from disturbances (e.g. flooding) and prey availability,

80 reducing territory size and fish mobility (Heggenes et al., 2007; Závorka et al., 2015). The

81 objectives of this study were to employ mark-recapture approaches over a period of $18-24$

82 months to determine (1) the degree of mobility (i.e. proportion of stationary and mobile

83 individuals) and extent of displacement distances, (2) seasonal variations in the pattern of

84 movements, and (3) the effect of habitat characteristics and biotic factors on trout movement. 85

\section{Materials and methods}

Study area

The marking and recapturing of individuals were conducted in three streams (Noguera

Pallaresa, Flamisell and Noguera Vallferrera) of the Segre River basin (Catalonia, NE Iberian Peninsula) (Fig. 1). The Segre is the largest catchment in the Southern Pyrenees (265 km long,

$9222580 \mathrm{~km}^{2}$ of basin area and about $100 \mathrm{~m}^{3} \mathrm{~s}^{-1}$ of average water flow), and is the main tributary of

93 the Ebro River, the river with the highest water flow in the Iberian Peninsula (annual mean is

94 about $426 \mathrm{~m}^{3} \mathrm{~s}^{-1}$ ) discharging into the Mediterranean Sea (for more details see Rovira, Alcaraz \&

95 Ibáñez, 2012). A tributary of the Segre River is the Noguera Pallaresa River (154 km of length

96 and $37.1 \mathrm{~m}^{3} \mathrm{~s}^{-1}$ of average flow), where three different reaches were selected (Fig. 1): the main

97 stem $\left(42^{\circ} 44^{\prime} \mathrm{N}, 0^{\circ} 58^{\prime} \mathrm{E}\right.$, hereafter $\left.\mathrm{NP}\right)$ and two tributaries, the Flamisell $\left(42^{\circ} 27^{\prime} \mathrm{N}, 0^{\circ} 59^{\prime} \mathrm{E}\right.$,

98 FLM) and the Noguera Vallferrera $\left(42^{\circ} 34^{\prime} \mathrm{N}, 1^{\circ} 19^{\prime} \mathrm{E}, \mathrm{NV}\right)$. The three reaches had a mean

99 stream width less than $10 \mathrm{~m}$, showed a high gradient, and channel morphology consisted

100 primarily of pool-run-riffle sequences under a forest canopy. Physical characteristics of study 
101 reaches are shown in Table 1. The hydrological regime is snow-fed, thus, the highest flows

102 generally occur in spring after snowmelt (Ebro Water Authority; http://www.chebro.es/). Brown

103 trout was the only fish species present and populations belong to the Mediterranean lineage

104 (Aparicio et al., 2005). During the study, sport fishing was closed in the study area.

105

106 Sampling design

107 Study reaches were continuous and ranged from $2400 \mathrm{~m}$ long in the NP, 1500 in the FLM to

$1081200 \mathrm{~m}$ long in the NV. The reaches were selected on the basis of being wadeable and the

109 absence of barriers to fish movement or significant tributaries within the study boundaries. Each

110 reach was divided into 25-40 m-long sections (mean length: $30.6 \mathrm{~m} \pm 4.3 \mathrm{SD}$ ), the boundaries of

111 which usually coincided with habitat discontinuities in the channel morphology (pool-run-riffle

112 sequence). Brown trout were marked in October 1992 in NP and in March 1993 in NV and FLM.

113 Four subsequent mark-recapture sampling events were conducted in each reach: NP was sampled

114 in 1993 (May and October) and 1994 (July and October), and both NV and FLM reaches were

115 sampled in 1993 (July and October) and 1994 (July and October). Autumn surveys (October)

116 were performed just prior or at the beginning of the spawning season, which in the study area

117 occurs from the end of October to early December. Therefore, movement data from October

118 sampling included the possible fish displacements related to spawning. Sampling sections were

119 isolated with block nets (mesh size $5 \mathrm{~mm}$ ) and three-pass electrofishing removal was conducted

120 in an upstream direction (500 V, 1.0 A pulsed DC). Captured fish were anaesthetised (MS-222

121 solution), measured for fork length (FL, mm), and weighed (g). Sex was determined externally

122 for mature individuals in autumn (i.e. October) surveys by the production of milt or visible 
123 evidence of eggs beneath the body wall. The adipose fin was clipped on all captured fish, which

124 constituted a permanent batch mark to distinguish recaptured individuals.

125 All fish larger than $120 \mathrm{~mm}$ FL (corresponding at least to age 1+ individuals, see

126 Supplementary Figure 1-3) were tagged with uniquely coded Visible Implant Tags (VI-tags;

127 Northwest Marine Technology, Shaw Island, Washington, USA) in the adipose tissue posterior

128 to eye. Fish smaller than $120 \mathrm{~mm}$ were not tagged, because the tissue available for placing the

129 tag was too thin, thus leading to extremely low retention rates (Niva, 1995). After handling, fish

130 were allowed to recover from anaesthesia and released into the mid-point of the capture section.

131 In recapture surveys, each fish's VI-tag code was read, and those untagged fish larger than 120

$132 \mathrm{~mm}$ FL (i.e. captured for the first time or having lost the VI-tag) were tagged following the 133 above procedure.

134 Habitat variables were measured along transects perpendicular to the flow at 10-m intervals.

135 Water depth and mean water velocity (at 0.6 times total water depth) were measured every $1 \mathrm{~m}$

136 along transects, and averaged for each section. For each transect, the percent cover of each

137 substrate category (Table 1) was visually estimated, averaged per section and an index of

138 substrate coarseness was derived for each section following Bain, Finn \& Booke (1985). Fish

139 cover was estimated as the percentage area of a section covered by woody debris, rocks or

140 undercut banks.

141 Permission for electrofishing and capture of $S$. trutta individuals was approved by the

142 competent authorities: Departament de Medi Ambient i Habitatge de la Generalitat de Catalunya

143 (current Departament d'Agricultura, Ramaderia, Pesca, Alimentació i Medi Natural) (SF/602) of

144 the regional authorities of Catalonia. 
147 Data analyses

148 Fish movement (i.e. distance covered) was measured from the midpoint of the recapture

149 section to the midpoint of its previous capture section. A movement distance of $0 \mathrm{~m}$ was

150 assigned to individuals captured and recaptured in the same section. Thus, the minimum

151 detectable movement was the distance between two or more sections (i.e. larger than 25-40 m).

152 Movement patterns were quantified using frequency distributions (two-tailed) of distances

153 moved. Positive values were assigned to upstream movements and negative values to

154 downstream movements. Mark-recapture studies are generally biased since long movements are

155 less frequently measured than short distances (Albanese, Angermeier \& Gowan, 2003). To assess

156 this source of bias, all movement observations were weighted by determining the total possible

157 movements sampled for each distance and weighting the under-sampled distances (Porter \&

158 Dooley, 1993; Albanese, Angermeier \& Gowan, 2003). The movement distributions were not

159 significantly different after adjustment (Kolmogorov-Smirnov test, $P>0.40$ for all comparisons),

160 suggesting a good study design (Porter \& Dooley, 1993). Therefore, unweighted distributions

161 were used for all analyses.

162 Trout were classified as moving (individuals leaving the home section between sampling

163 events) and non-moving (sedentary individuals not leaving the home section) individuals.

164 Differences in distance covered by moving fish among streams and sampling events were

165 analysed with analysis of variance (two-way ANOVA). The kurtosis and skewness of the

166 frequency distribution of distances moved by brown trout were obtained with the package

167 moments (version 0.14 ) for program $\mathrm{R}$, and were used as an indicator of individual level

168 variation in movement behaviour (Skalski \& Gilliam, 2000). Dispersal range was estimated as 
169 the distance between the two most distant sections in which an individual was recorded, and only

170 fish captured at least in three sampling events (elapsed time between first and last capture was 7

171 to 24 months) were included in the analyses. The frequency distribution of dispersal range was

172 fitted to a two-group exponential function (Rodriguez 2002):

$$
f(x)=p \frac{\lambda_{s}}{2} e^{-\lambda_{s} x}+(1-p) \frac{\lambda_{m}}{2} e^{-\lambda_{m} x}
$$

where $x$ is the distance covered, $\lambda_{s}$ correspond to the inverse of mean dispersal distance for the stationary component, $\lambda_{m}$ correspond to the inverse of mean dispersal distance for the mobile component, $p$ is the proportion of stationary individuals, and thus, $1-p$ is the proportion of mobile individuals. Parameters $p, \lambda_{s}$ and $\lambda_{m}$ are estimated from movement data (see Rodriguez, 2002). Estimated movement parameters were then compared to the expected movement parameters for stream-resident brown trout obtained with the package fishmove (version 0.3-3)

180 for program $\mathrm{R}$, which models dispersal in relation to species, fish length, aspect ratio of the 181 caudal fin, stream size and duration of the study (Radinger \& Wolter, 2014).

182 In order to examine the relationship between fish growth rate and movement, the specific 183 growth rate $\left(\mathrm{SGR}\right.$, in $\%$ day $\left.^{-1}\right)$ for a given fish in the summer period was calculated as $\mathrm{SGR}=$

184 (ln(final fork length) $-\ln ($ initial fork length) $) \times 100 /$ (days between captures). Differences in the growth rate-fork length relationship between moving and non-moving individuals were tested with analysis of covariance (ANCOVA), for each stream. Software Pop/Pro 1.0 (Kwak, 1992) was used to estimate population size per section and capture probability per size class (i.e. trout smaller and larger than $120 \mathrm{~mm}$ ) from the three-pass electrofishing data. Fish density

189 (individuals $\left.\mathrm{ha}^{-1}\right)$ and biomass $\left(\mathrm{kg} \mathrm{ha}^{-1}\right)$ per section were estimated by dividing number and weight by the area sampled. Variations in fish density and biomass among streams were analysed

191 with multiple analysis of variance (MANOVA). MANOVA is used when several dependent 
192 variables are measured on each sampling unit. MANOVA compares the mean vectors of $\mathrm{k}$

193 groups; whereas equality of the mean vector implies that the k means are equal for each variable,

194 if two means differ for just one variable then we conclude that the mean vectors of the k groups

195 are different (Sokal \& Rohlf, 1995). We used $\eta^{2}$ (eta squared) as a measure of effect size (i.e.

196 importance of factors). Similarly to $r^{2}, \eta^{2}$ is the proportion of variation explained for a certain

197 effect.

198 The effects of biotic and abiotic stream features of sampling sections on trout departure ratio

199 (defined as the proportion of individuals leaving section $i$ from the total number of recaptures of

200 trout initially marked in section $i$ ) were analysed with Generalized Linear Models (GLMs). We

201 performed a global analysis including the three different streams, and then streams were analysed

202 separately. In each case, an information-theoretic approach was used to find the best

203 approximating models (Burnham \& Anderson, 2002). GLMs were built including all possible

204 combinations of environmental and biotic variables, excluding interactions, due to the large

205 number of variables included. Two additional criteria were used to define the set of candidate

206 models: those performing significantly better than the null model and with a variance inflation

207 factor $\leq 5$, in order to avoid multicollinearity effects. The second order Akaike Information

208 Criterion (AICc) was used to assess the degree of support for each candidate model. AICc was

209 rescaled to obtain $\Delta \mathrm{AICc}$ values $\left(\Delta \mathrm{AICc}=\mathrm{AICc}_{i}-\right.$ minimum $\left.\mathrm{AICc}\right)$, since models with $\Delta \mathrm{AICc} \leq$

2102 have the most substantial support. The relative plausibility of each candidate model was

211 assessed by calculating Akaike's weights $\left(w_{\mathrm{i}}\right)$, which range from 0 to 1 , and can be interpreted as

212 the probability that a given model is the best model in the candidate set. Because no model was

213 clearly the best one (i.e. $\left.w_{\mathrm{i}} \geq 0.9\right)$ model-average regression coefficients were calculated using

214 the relative importance of each independent variable (Burnham \& Anderson, 2002). Model- 
215 averaged coefficients were compared with those from the full model to assess the impact of

216 model selection bias on parameter estimates. All data analyses were performed with R software

217 version 3.3.2.

218

219 Results

220 Recapture rates and VI-tag retention

221 A total of 13,340 individuals were captured and fin-clipped during the study period, and

2227050 of them were larger than $120 \mathrm{~mm}$ FL and tagged (NP: 2201; FLM: 1181; NV: 3668). Mean

223 FL of tagged fish was $165.1 \mathrm{~mm} \pm 34.7 \mathrm{SD}$ in the NP, $162.8 \mathrm{~mm} \pm 38.1 \mathrm{SD}$ in the FLM and

$224183.0 \mathrm{~mm} \pm 42.1 \mathrm{SD}$ in the NV. Capture probabilities estimated from electrofishing depletion

225 surveys ranged from 0.40 to $0.88(\mu=0.65)$ for trout larger than $120 \mathrm{~mm}$, and from 0.14 to 0.49

$226(\mu=0.38)$ for individuals smaller than $120 \mathrm{~mm}$. The proportion of the new trout individuals (i.e.

227 fish not fin-clipped) larger than $120 \mathrm{~mm}$ FL captured for the first time was similar among

228 streams and decreased sharply until the end of the study, with a maximum reduction of about 60

$229 \%$ between the first and the second sampling (Figure 2). The decline in the proportion of new

230 individuals smaller than $120 \mathrm{~mm}$ FL captured in the second survey was less pronounced (Figure

231 2), probably because of recruitment and reduced capturability. Despite the high recapture rates,

232 the recovery percentage of VI-tag (i.e. fish larger than $120 \mathrm{~mm}$ ) was relatively low due to tag

233 loss. Overall, mean VI-tag retention rate was $45.0 \%$ but varied in relation to fish size. Trout

234 smaller than $180 \mathrm{~mm} \mathrm{FL}$ at tagging showed mean retention rates of $32.4 \%$ whereas the rate was

$23574.9 \%$ for trout larger than $240 \mathrm{~mm}$ FL.

236

237 Movements and dispersal patterns 
Overall, movements of brown trout between consecutive sampling events were relatively

239 short since the $53.4 \%$ (ranging between 48.1 and $54.4 \%$ ) of the total recaptures $(N=3073)$ were

240 in the same stream section of previous capture. When fish moving out from home section were

241 analysed separately, most of the displacements were between contiguous sections, and long-

242 range movements were infrequent; for instance, only the $2.18 \%$ of the movements were over

$243400 \mathrm{~m}$ in NV, being $2.37 \%$ in NP and $3.35 \%$ in FLM. Distance covered by fish moving out

244 from home section was not significantly related to fork length (ANCOVA, $P>0.29$ in all rivers)

245 or length $\times$ season interaction $(P>0.15)$, so an ANOVA was used. Distance covered by fish

246 showed significant temporal variations in both the NP (ANOVA, $F_{3,426}=4.49, P=0.004, \eta^{2}=$

$2470.24)$ and $\mathrm{NV}\left(F_{3,795}=9.45, P<0.0001, \eta^{2}=0.26\right)$ streams, with trout covering larger distances

248 in autumn (Figure 3), but seasonal differences were not significant in the FLM stream $\left(F_{3,198}=\right.$

$2491.08, P=0.36)$.

250 In the three streams the distance-frequency distributions were highly leptokurtic and skewed 251 to the right, the Kurtosis values were 28.9 for FLM, 19.6 for NV and 144.6 for NP. The two-

252 group exponential model provided a good fit to the frequency distributions of dispersal range

253 (Figure 4). Based on the estimates of $p$, the proportion of stationary individuals in the three

254 streams ranged from 71.1 to $87.5 \%$ and, thus, the percentage of mobile individuals varied from

25512.5 to $28.9 \%$ (Table 2 ). The mean dispersal range, calculated as $1 / \lambda$ (see methods), ranged

256 from 20.7 to $45.4 \mathrm{~m}$ for the stationary group and from 229.4 to $540.5 \mathrm{~m}$ for the mobile group

257 (Table 2). These dispersal ranges were similar to that expected by the general model for stream

258 resident brown trout estimated with fishmove package, which calculates a mean movement

259 distance of $25.1 \mathrm{~m}$ for the stationary group and $428.3 \mathrm{~m}$ for the mobile group. 
261 Influence of biotic and abiotic factors on movements

262 Several biotic and abiotic factors were associated with brown trout movement patterns.

263 Overall, the information theoretic analysis of the candidate set of GLMs selected eight plausible

264 models (i.e. $\triangle \mathrm{AICc}<2)$ to explain variability in departure ratio (i.e. proportion of individuals

265 leaving section $i$ from the total number of recaptures of trout initially marked in section $i$ ) in

266 relation to stream features. The best explanatory variables (SP values in Table 3), were water

267 depth, fish cover and fish biomass. Interestingly, fish biomass was preferentially selected over

268 density, despite the high correlation between them (Pearson's $r=0.94, N=246, P<0.0001$ ). All

269 three variables (water depth, cover and biomass) were negatively related to departure ratio; in

270 contrast, organic substrate, water velocity, substrate coarseness and fish density had a positive

271 relationship with departure ratio. Season had the weakest relationship with trout departure ratio.

272 However, the lower correlation between observed and predicted values and larger parameters

273 bias indicated some differences among streams (Table 3, Supplementary Table 1). When

274 analysed separately by streams, similar patterns were observed, with some variations linked to

275 specific stream habitat characteristics (Table 1, Table 3). For instance, in the FLM stream where

276 higher departure ratios (ANOVA, $\left.F_{2,243}=11.67, P<0.0001\right)$ and lower biomass and density

277 values (MANOVA, Wilks's $\lambda=0.513 ; F_{4,484}=47.92 ; P<0.0001$ ) were reported, physical

278 features (i.e. fish cover, substrate coarseness and water depth) and fish biomass were the best

279 explanatory variables. Seasonal variation in departure ratio confirmed previous observed results

280 (Figure 3); thus, while no seasonal differences were observed in the FLM stream, autumn

281 departure ratio (i.e. pre-spawn movements) was higher in the NV stream, and lower in the NP

282 stream. In the NV stream, along with fish biomass and season, the most important variable was

283 water velocity, all negatively related to departure ratio. In the NP stream, fish density and 
284 biomass showed a contrasting pattern (Table 3), which might be explained by differences in fish

285 length, since NP fish were the smallest (ANOVA, $F_{2,3070}=184.60, P<0.0001$ ).

286 Moving brown trout were significantly larger than non-moving individuals in the three

287 study streams $\left(P<0.029\right.$ and $\eta^{2}>0.16$, in all cases $)$, but distances moved were not significantly

288 correlated with trout fork length ( $P>0.15$, in all cases). In both FLM and NV streams, specific

289 growth rate of moving trout $\left(\mu \pm\right.$ standard error: $0.132 \pm 0.006 \%$ day $^{-1}$ in the FLM and $0.057 \pm$

$2900.002 \%$ day $^{-1}$ in the NV) was significantly higher than non-moving trout $(0.103 \pm 0.005$ and

$2910.050 \pm 0.001 \%$ day $\left.^{-1}\right)\left(\right.$ ANCOVA, $F_{1,242}=5.73, P<0.05, \eta^{2}=0.19$, in FLM, and $F_{1,1262}=$

$2926.07, P<0.05, \eta^{2}=0.28$ in NV), but no significant differences were observed in the NP stream

$293\left(0.048 \pm 0.002 \%\right.$ day $^{-1}$ for moving fish and $0.052 \pm 0.002 \%$ day $^{-1}$ for non-moving fish $)\left(F_{1,327}=\right.$

$2941.06, P=0.31)$.

295

296

\section{Discussion}

297 Movements and dispersal patterns

298

299

Brown trout exhibited limited mobility and few fish performed long-range movements.

300 Between successive sampling events, a significant proportion of fish moved from their home

301 section, but most of them moved less than $100 \mathrm{~m}$ and settled in contiguous sections (i.e. adjacent

302 channel units). Individuals move in response to changing resource abundance and quality, thus

303 movement extent should depend on the distance to a suitable habitat (Fausch et al., 2002), with

304 longer movement distances presumably occurring when suitable habitats are widely spaced

305 (Wiens, 2001). Therefore, the low mobility exhibited by brown trout from this study could

306 indicate that the different habitats required to complete its life cycle are in spatial proximity 
307 (Northcote, 1992; Gowan et al., 1994; Albanese, Angermeier \& Dorai-Raj, 2004). Spatial habitat

308 heterogeneity is usually higher in small streams than in larger rivers, where habitat units are

309 more widely spaced (Gorman \& Karr, 1978), and habitat heterogeneity reduces territory size and

310 mobility (Heggenes et al., 2007). Consequently, limited movements of no more than a few

311 hundred meters are frequently reported for trout populations in small streams (Heggenes, 1988;

312 Knouft \& Spotila, 2002) when compared to those from large and long rivers, where longer

313 movements, up to several kilometres, have been observed (Clapp, Clark Jr \& Diana, 1990;

314 Young, 1994; Zimmer, Schreer \& Power, 2010). Therefore, the size of the study streams could

315 have influenced the limited range of movements observed (Woolnough, Downing \& Newton, 316 2009).

317 Although there was substantial intra-population variation in movement behaviour, the 318 studied populations were dominated by stationary individuals, in concordance with most of the 319 studies on movement in stream salmonids (Rodriguez, 2002, and references therein). Our results 320 also match the estimated movement parameters (i.e. proportion of stationary and mobile

321 individuals, and mean dispersal distances) provided by predictive models for stream-resident

322 brown trout (Radinger \& Wolter, 2014), for both the stationary and the mobile component. The

323 displacement range of the stationary component was less than 50 meters, and thus, is considered

324 as a restricted movement (Rodríguez, 2002). Despite being in low proportion, mobile individuals

325 are important since they are responsible for exchange between populations and successful

326 colonization of new habitats (Vera et al., 2010; Kennedy, Rosell \& Hayes, 2012).

327 Many studies dealing with brown trout movements showed a seasonal increase in mobility

328 due to upstream spawning migration and downstream movement for overwintering (Clapp, Clark

329 Jr \& Diana, 1990; Meyers, Thuemler \& Kornely, 1992; Ovidio et al., 1998). Our results showed 
330 temporal differences in the distance covered by moving fish, thus suggesting that seasonal

331 changes in environmental conditions or the reproductive cycle of fish affected trout movements.

332 There was an increase in distances moved in autumn surveys in both the NP and the NV stream,

333 just before the spawning period, although this cannot be considered a true spawning migration

334 because movement did not involve most of the population nor were distances moved long-range.

335 In streams where spawning sites are located in or near the rearing habitats, as occurred in the

336 studied reaches where gravel beds were widely distributed, spawning-related movements may be

337 minimal or involve short distances (Northcote, 1992; Nakamura, Maruyama \& Watanabe,

338 2002).

339 Movement data were based on recaptured (i.e. surviving) tagged fish, thus several potential

340 sources of bias could have affected our results. For instance, VI-tag insertion and adipose fin

341 clipping may result in different behaviour or mortality rate compared to the non-tagged fish.

342 However, studies on salmonid species suggest that adipose fin clipping and VI tag insertion do

343 not affect condition, growth or survival (e.g. Bryan \& Ney, 1994; Shepard et al., 1996), thus the

344 behaviour of tagged fish is representative of the population. Another potential source of bias

345 could be related to the relatively low percentage of VI-tags recovered, not only due to tag loss

346 but also to natural mortality, which is expected in a nearly two years study. Although it was not

347 measured, annual mortality for adult brown trout is estimated to be $43-72 \%$ in similar Pyrenean

348 rivers (Gouraud et al., 2000). Tag loss may bias abundance estimates from mark-recapture

349 methods (Frenette \& Bryant, 1996), but movement estimates are not biased since differences in

350 behaviour between tagged and tag-loss fish are not expected. Therefore, both mortality and tag

351 loss only affect movement estimates by reducing total data gathered, but this was avoided by

352 maximizing sample size increasing the number of fish tagged. Trout leaving the sampling area 
353 probably also accounted for a percentage of missed recaptures, thus leading to an

354 underestimation of long-range movements (Gowan et al., 1994). However, the high proportion of

355 recaptures of fin-clipped fish suggests that the emigration from the study area was proportionally

356 low compared to the trout population monitored (Gowan et al., 1994).

357

358 Relationship of habitat and biotic factors with brown trout movements

359

360

Fish movements are mediated by biotic and abiotic factors affecting individual fitness

361 (Gowan et al., 1994; Railsback et al., 1999; Bélanger \& Rodríguez, 2002). Our results showed

362 that departure ratio was not consistently linked to particular habitat features, suggesting that

363 movement behaviour probably does not depend on a single parameter but on a complex

364 combination and availability of several factors. For instance, fish inhabiting shallower sections in

365 the FLM stream showed higher departure ratios than those from deeper waters. Among the study

366 streams, the FLM had the lowest mean water depth, therefore deeper waters, which confer

367 greater protection against predators (Lonzarich \& Quinn, 1995), were a valuable resource

368 motivating trout movement. In the same sense, sections with higher fish cover in the FLM and

369 NP stream showed lower departure ratios, probably because of the refugia provided from

370 predators and fast currents (Harvey, Nakamoto \& White, 1999; Ayllón et al., 2014). Finally, the

371 negative effect of water velocity on departure ratio in the NV stream could be mediated by an

372 increase in prey delivery rate in high velocity areas (Leung, Rosenfeld \& Bernhardt, 2009), thus

373 promoting residency.

374 Movements of stream fishes have been associated with fish size and growth rates. There is

375 evidence from previous studies that movement distances increase with fish length, particularly 
376 for trout larger than 300-400 mm FL (Meyers, Thuemler \& Kornely, 1992; Young, 1994; Quinn

$377 \&$ Kwak, 2011). In the three study streams moving fish were larger than non-moving trout, but

378 there was no relationship between distance moved and fish size. Results are probably skewed by

379 the scarcity of large fish, since only few individuals $(<0.5 \%)$ exceeded $300 \mathrm{~mm}$ FL, or the fact

380 that large dominant fish could displace subordinate individuals, thus leading a movement

381 cascade of fish of all sizes and obscuring length-related patterns (Gowan \& Fausch, 2002;

382 Railsback \& Harvey, 2002). Mobility is energetically expensive and increases risk of predation

383 since fish have to move through unfamiliar space (Pépino, Rodríguez \& Magnan, 2015).

384 Nevertheless, mobility appeared to confer an advantage on trout growth rate. Several authors

385 have reported that, when resources are scattered, mobile fish maximize food supply and

386 compensate energetic costs of movement, thus increasing growth rate (e.g. Hilderbrand \&

387 Kershner, 2004; Závorka et al., 2015).

388

389

Management implications

390

391 Most of the remnant brown trout populations of the Mediterranean lineage are confined to

392 streams where many artificial in-stream barriers have been built for hydropower generation. For

393 example, more than 400 weirs and dams are distributed in the Spanish Pyrenean rivers (Espejo \&

394 García, 2010), mainly for small-scale hydropower production. Barriers can restrict movement

395 pathways among critical habitats for spawning, feeding or refuge (Dunham, Vinyard \& Rieman,

396 2011), thus stream longitudinal connectivity is a key consideration in the management and

397 conservation of the brown trout. The low rate of average movement at population level reported

398 here suggests that management of brown trout populations in headwater streams, similar to those 
399 studied here, should focus on the conserving high quality habitats, whereas stream connectivity

400 may not be as critical since relatively small stream length may provide sufficient habitat to meet

401 all life-history needs. However, connectivity could become important when other anthropogenic

402 impacts are present or the population verges the threshold of the minimum viable size

403 (Hilderbrand \& Kershner, 2011). Then, the importance of medium and long distance movements

404 may be higher for population persistence, by allowing fish to withstand locally unfavourable

405 conditions or favouring the recolonization after the disturbance (Fausch et al., 2009).

406 Finally, since brown trout is an important game species, in populations with limited

407 dispersal fishing regulations could exert a high influence on trout abundance. Overfishing and

408 depletion of fishery stocks seem more probable in stream reaches inhabited by trout populations

409 with low mobility because substantial immigration of new individuals or eventual displacement

410 of fish to safer areas (i.e. closed fishing reaches) are infrequent. To improve native trout

411 abundance in streams with significant fishing pressure, no-kill regulations are advised or, at least,

412 hardening existing regulations to avoid overexploitation.

413

\section{Acknowledgements}

415 Authors wish to thank the many people who assisted to fieldwork, especially to F. Casals,

416 M. A. Puig, J. M. Olmo, M. J. Vargas, J. Malo, C. Franco and J. Laborda. We are grateful to the

417 anonymous reviewers for their feedback which was very helpful in improving the manuscript.

419 References 
420 Albanese B, Angermeier PL, Gowan C. 2003. Designing mark-recapture studies to reduce

421 effects of distance weighting on movement distance distributions of stream fishes.

422 Transactions of the American Fisheries Society 132:925-939. DOI: 10.1577/T03-019

423

424

425

426

427

428

429

430

431

432

Albanese B, Angermeier PL, Dorai-Raj S. 2004. Ecological correlates of fish movement in a network of Virginia streams. Canadian Journal of Fisheries and Aquatic Sciences 61:857869. DOI: $10.1139 / \mathrm{f04-096}$

Almodóvar A, Nicola GG. 2004. Angling impact on conservation of Spanish stream-dwelling brown trout Salmo trutta. Fisheries Management and Ecology 11:173-182. DOI: 10.1111/j.1365-2400.2004.00402.x

Almodóvar A, Nicola GG, Ayllón D, Elvira B. 2012. Global warming threatens the persistence of Mediterranean brown trout. Global Change Biology 18:1549-1560. DOI:10.1111/j.13652486.2011.02608.x

Aparicio E, Sostoa A. 1999. Pattern of movements of adult Barbus haasi in a small Mediterranean stream. Journal of Fish Biology 55:1086-1095. DOI:10.1111/j.10958649.1999.tb00743.x

Aparicio E, García-Berthou E, Araguas RM, Martínez P, García-Marín JL. 2005. Body pigmentation pattern to assess introgression by hatchery stocks in native Salmo trutta from Mediterranean streams. Journal of Fish Biology 67:931-949. DOI: 10.1111/j.10958649.2005.00794.x

Ayllón D, Nicola GG, Parra I, Elvira B, Almodóvar A. 2014. Spatio-temporal habitat selection shifts in brown trout populations under contrasting natural flow regimes. Ecohydrology 7:569-579. DOI:10.1002/eco.1379 
442 Bain MB, Finn JT, Booke HE. 1985. Quantifying stream substrate for habitat analysis studies.

443 North American Journal of Fisheries Management 5:499-500. DOI: 10.1577/1548-

444 8659(1985)5<499:QSSFHA>2.0.CO;2

445

10.1577/1548-8659(1985)5<499:QSSFHA $>2.0$.

446

447

448

449

450

451

452

453

454

455

456

457

458

459

460

461

462

463

464

Bélanger G, Rodríguez MA. 2002. Local movement as a measure of habitat quality in stream salmonids. Environmental Biology of Fishes 64:155-164. DOI: 10.1023/A:1016044725154

Benejam L, Saura-Mas S, Bardina M, Solà C, Munné A, García-Berthou E. 2016. Ecological impacts of small hydropower plants on headwater stream fish: from individual to community effects. Ecology of Freshwater Fish 25:295-306. DOI:10.1111/eff.12210

Bernatchez L. 2001. The evolutionary history of brown trout (Salmo trutta L.) inferred from phylogeographic, nested clade and mismatch analyses of mitochondrial DNA variation. Evolution 55:351-379. DOI: 10.1554/0014-3820(2001)055[0351:TEHOBT]2.0.CO;2

Bryan RD, Ney JJ. 1994. Visible implant tag retention by and effects on condition of a stream population of brook trout. North American Journal of Fisheries Management 14:216-219. DOI: $10.1577 / 1548-8675(1994) 014<0216$ :VITRBA $>2.3 . C O ; 2$

Burnham KP, Anderson DR. 2002. Model Selection and Multimodel Inference: A Practical Information-Theoretic Approach. New York: Springer-Verlag.

Burrell KH, Isely JJ, Bunnell Jr DB, Van Lear DH, Dolloff CA. 2000. Seasonal movement of brown trout in a southern Appalachian river. Transactions of the American Fisheries Society 129:1373-1379. 10.1577/1548-8659(2000)129<1373:SMOBTI>2.0.CO;2Cl_DF, Clark Jr RD, Diana JS. 1990. Range, activity, and habitat of large, free-ranging brown trout in a Michigan stream. Transactions of the American Fisheries Society 119:1022-1034. DOI: 10.1577/1548-8659(1990)119<1022:RAAHOL $>2.3 . C O ; 2$ 
465 Cortey M, Pla C, García-Marín JL. 2004. Historical biogeography of Mediterranean trout.

466 Molecular Phylogenetics and Evolution 33:831-844. DOI:10.1016/J.YMPEV.2004.08.012

467 Espejo C, García R. 2010. Agua y energía: producción hidroeléctrica en España. Investigaciones 468 Ge@áficas 51:107-129.

469 Fausch KD, Torgersen CE, Baxter CV, Li HW. 2002. Landscapes to riverscapes: bridging the 470 gap between research and conservation of stream fishes. BioScience 52:483-498. DOI: 10.1641/0006-3568(2002)052[0483:LTRBTG]2.0.CO;2

472 Fausch KD, Rieman BE, Dunham JB, Young MK, Peterson DP. 2009. Invasion versus isolation: 473 trade-offs in managing native salmonids with barriers to upstream movement. Conservation 474 Biology 23:859-870. DOI: 10.1111/j.1523-1739.2008.01159.x

475 Frenette BJ, Bryant MD. 1996. Evaluation of visible implant tags applied to wild coastal 476 cutthroat trout and dolly varden in Margaret Lake, Southeast Alaska. North American Journal of Fisheries Management 16:926-930. DOI: 10.1577/15488675(1996)016<0926:EOVITA >2.3.CO;2

479 Gorman OT, Karr JR. 1978. Habitat structure and stream fish communities. Ecology 59:507515. DOI: $10.2307 / 1936581$

481 Gouraud V, Baran P, Lim P, Sabaton C. 2000. Dynamics of a population of brown trout (Salmo 482 trutta) and fluctuations in physical habitat conditions - experiments on a stream in the 483 Pyrenees; first results. In: Cowx IG, ed. Management and ecology of river fisheries. Oxford: $484 \quad$ Fishing News Books, Blackwell Science, 126-142.

485 Gowan C, Young MK, Fausch KD, Riley SC. 1994. Restricted movement in resident stream 486 salmonids: A paradigm lost? Canadian Journal of Fisheries and Aquatic Sciences 51:2626487 2637. DOI: $10.1139 / \mathrm{f} 94-262$ 
488 Gowan C, Fausch KD. 2002. Why do foraging stream salmonids move during summer?

489 Environmental Biology of Fishes 64:139-153. DOI: 10.1023/A:1016010723609

490 Harvey BC, Nakamoto RJ, White JL. 1999. Influence of large woody debris and a bankfull flood 491 on movement of adult resident coastal cutthroat trout (Oncorhynchus clarki) during fall and 492 winter. Canadian Journal of Fisheries and Aquatic Sciences 56:2161-2166. DOI:

493 $10.1139 / \mathrm{f} 99-154$

494 Heggenes J. 1988. Effect of experimentally increased intraspecific competition on sedentary 495 adult brown trout (Salmo trutta) movement and stream habitat choice. Canadian Journal of Fisheries and Aquatic Sciences 45:1163-1172. DOI: 10.1139/f88-139

Heggenes J, Omholt PK, Kristiansen JR, Sageie J, Økland F, Dokk JG, Beere MC. 2007. Movements by wild brown trout in a boreal river: response to habitat and flow contrasts. Fisheries Management and Ecology 14:333-342. DOI: 10.1111/j.1365-2400.2007.00559.x.

500 Hesthagen T. 1988. Movements of brown trout, Salmo trutta, and juvenile Atlantic salmon, 501 Salmo salar, in a coastal stream in northern Norway. Journal of Fish Biology 32:639-653. DOI:10.1111/j.1095-8649.1988.tb05404.x

503 Hilderbrand RH, Kershner JL. 2004. Are there differences in growth and condition between 504 mobile and resident cutthroat trout? Transactions of the American Fisheries Society 133:1042-1046. DOI: 10.1577/T03-015.1

506 Hilderbrand RH, Kershner JL. 2011. Conserving Inland Cutthroat Trout in Small Streams: How 507 Much Stream is Enough? North American Journal of Fisheries Management 20:513-520. 
509 Dunham JB, Vinyard GL, Rieman BE. 2011. Habitat Fragmentation and Extinction Risk of

$510 \quad$ Lahontan Cutthroat Trout. North American Journal of Fisheries Management 17:1126-1133.

$511 \quad$ DOI: $10.1577 / 1548-8675(1997) 017<1126: H F A E R O>2.3 . C O ; 2$

512 Kennedy RJ, Rosell R, Hayes J. 2012. Recovery patterns of salmonid populations following a

513 fish kill event on the River Blackwater, Northern Ireland. Fisheries Management and

514 Ecology 19:214-223. DOI:10.1111/j.1365-2400.2011.00819.x

515 Knouft JH, Spotila JR. 2002. Assessment of movements of resident stream brown trout, Salmo

516 trutta L., among contiguous sections of stream. Ecology of Freshwater Fish 11:85-92. DOI:

$517 \quad$ 10.1034/j.1600-0633.2002.110203.x

518 Kwak TJ. 1992. Modular microcomputer software to estimate fish population parameters,

519 production rates and associated variance. Ecology of Freshwater Fish 1:73-75. DOI:

520

10.1111/j.1600-0633.1992.tb00009.x

521 Leung ES, Rosenfeld JS, Bernhardt JR. 2009. Habitat effects on invertebrate drift in a small trout

522 stream: implications for prey availability to drift-feeding fish. Hydrobiologia 623:113-125. DOI: $10.1007 / \mathrm{s} 10750-008-9652-1$

524 Lonzarich DG, Quinn TP. 1995. Experimental evidence for the effect of depth and structure on 525 the distribution, growth, and survival of stream fishes. Canadian Journal of Zoology 73:2223-2230. DOI: 10.1139/Z95-263

527 Lucas MC, Baras E. 2001. Migration of Freshwater Fishes. Oxford: Blackwell Science.

528 Meyers LS, Thuemler TF, Kornely GW. 1992. Seasonal movements of brown trout in northeast

529 Wisconsin. North American Journal of Fisheries Management 12:433-441. DOI:

530 10.1577/1548-8675(1992)012<0433:SMOBTI >2.3.CO;2 
531 Nakamura T, Maruyama T, Watanabe S. 2002. Residency and movement of stream-dwelling

532 Japanese charr, Salvelinus leucomaenis, in a central Japanese mountain stream. Ecology of

533 Freshwater Fish 11:150-157. DOI: 10.1034/j.1600-0633.2002.00014.x

534 Niva T. 1995. Retention of visible implant tags by juvenile brown trout. Journal of Fish Biology

535 46:997-1002. DOI:10.1111/j.1095-8649.1995.tb01404.x

536

537

538

539

540

541

542

543

544

545

546

547

548

549

550

551

552

553

Northcote T. 1992. Migration and residence in stream salmonids-some ecological considerations and evolutionary consequences. Nordic Journal of Freshwater Research 67:5-17.

Ovidio M, Baras E, Goffaux D, Birtles C, Philippart JC. 1998. Environmental variability rules the autumn migration of brown trout (Salmo trutta) in the Belgian Ardennes. Hydrobiologia 371/372:263-274. DOI: 10.1023/A:1017068115183

Pépino M, Rodríguez MA, Magnan P. 2015. Shifts in movement behavior of spawning fish under risk of predation by land-based consumers. Behavioral Ecology 26:996-1004. DOI: 10.1093/beheco/arv038

Porter JH, Dooley JL. 1993. Animal dispersal patterns: a reassessment of simple mathematical models. Ecology 74:2436-2443. DOI: 10.2307/1939594

Quinn JW, Kwak TJ. 2011. Movement and survival of brown trout and rainbow trout in an Ozark Tailwater river. North American Journal of Fisheries Management 31:299-304. DOI:

$$
10.1080 / 02755947.2011 .576204
$$

Radinger J, Wolter C. 2014. Patterns and predictors of fish dispersal in rivers. Fish and

$$
\text { Fisheries 15:456-473. DOI:10.1111/faf.12028 }
$$

Railsback SF, Lamberson RH, Harvey BC, Duffy WE. 1999. Movement rules for individualbased models of stream fish. Ecological Modelling 123:73-89. DOI:10.1016/S03043800(99)00124-6 
554 Railsback SF, Harvey BC. 2002. Analysis of habitat-selection rules using an individual-based

555 model. Ecology 83:1817-1830. DOI: 10.1890/0012-

$5569658(2002) 083[1817: A O H S R U] 2.0 . C O ; 2$

557 Rasmussen JE, Belk MC. 2017. Individual Movement of Stream Fishes: Linking Ecological

558 Drivers with Evolutionary Processes. Reviews in Fisheries Science \& Aquaculture 25:70-83.

559 DOI: $10.1080 / 23308249.2016 .1232697$

560 Rodríguez M. 2002. Restricted movement in stream fish: the paradigm is incomplete, not lost.

$561 \quad$ Ecology 83:1-13. DOI: $10.2307 / 2680115$

562 Rovira A, Alcaraz C, Ibáñez C. 2012. Spatial and temporal dynamics of suspended load at-a-

563 cross-section: The lowermost Ebro River (Catalonia, Spain). Water research 46:3671-3681.

$564 \quad$ DOI: $10.1016 /$ j.watres.2012.04.014

565 Shepard BB, Robison-Cox J, Ireland SC, White RG. 1996. Factors influencing retention of

566 visible implant tags by westslope cutthroat trout in-habiting headwater streams of Montana.

567 NorthAmerican Journal of Fisheries Management 16:913-920. DOI: 10.1577/1548-

568 8675(1996)016<0913:FIROVI >2.3.CO;2

569 Skalski GT, Gilliam JF. 2000. Modelling diffusive spread in a heterogeneous population: A

570 movement study with stream fish. Ecology 81:1685-1700. DOI: 10.1890/0012-

$5719658(2000) 081[1685: M D S I A H] 2.0 . C O ; 2$

572 Sokal RR, Rohlf FJ. 1995. Biometry: the principles and practice of statistics in biological

573 research. Freeman, New York.

574 Vatland S, Caudron A. 2015. Movement and early survival of age-0 brown trout. Freshwater

575 Biology 60:1252-1262. DOI:10.1111/fwb.12551 
576 Vera M, Sanz N, Hansen MM, Almodóvar A, García-Marín JL. 2010. Population and family

577 structure of brown trout, Salmo trutta, in a Mediterranean stream. Marine and Freshwater

$578 \quad$ Research 61:672-681. DOI: 10.1071/MF09098

579 Wiens JA. 2001. The landscape context of dispersal. In: Clobert J, Danchin E, Dhondt AA,

$580 \quad$ Nichols JD, eds. Dispersal. New York: Oxford University Press, 97-109.

581 Woolnough DA, Downing JA, Newton TJ. 2009. Fish movement and habitat use depends on

582 water body size and shape. Ecology of Freshwater Fish 18:83-91. DOI: 10.1111/j.1600-

$583 \quad 0633.2008 .00326 . x$

584 Young MK. 1994. Mobility of brown trout in southcentral Wyoming streams. Canadian Journal 585 of Zoology 72:2078-2083. DOI: 10.1139/z94-278

586 Závorka L, Aldvén D, Näslund J, Höjesjö J, Johnsson JI. 2015. Linking lab activity with growth 587 and movement in the wild: explaining pace-of-life in a trout stream. Behavioral Ecology

$588 \quad 26: 877-884$. DOI: $10.1093 /$ beheco/arv029

589 Zimmer M, Schreer JF, Power M. 2010. Seasonal movement patterns of Credit River brown trout 590 (Salmo trutta). Ecology of Freshwater Fish 19:290-299. DOI: 10.1111/j.1600-

$591 \quad 0633.2010 .00413 . x$

592 


\section{Table $\mathbf{1}$ (on next page)}

Stream features during the sampling period.

FLM: Flamisell, NP: Noguera Pallaresa, and NV: Noguera Vallferrera. Mean \pm standard deviation, when necessary, is shown. 


\begin{tabular}{|c|c|c|c|}
\hline \multirow{2}{*}{ Variable } & \multicolumn{3}{|c|}{ Stream } \\
\hline & FLM & NP & $\mathbf{N V}$ \\
\hline Length (m) & 1500 & 2400 & 1200 \\
\hline Mean elevation (m) & 1250 & 1780 & 1175 \\
\hline Mean slope $\left(\mathrm{m} \mathrm{km}^{-1}\right)$ & 53.3 & 20.8 & 62.5 \\
\hline Mean base flow $\left(\mathrm{m}^{3} \mathrm{~s}^{-1}\right)$ & 1.52 & 0.95 & 1.29 \\
\hline Temperature range $\left({ }^{\circ} \mathrm{C}\right)$ & $4.2-15.3$ & $0.1-15.1$ & $2.5-15.4$ \\
\hline $\mathrm{pH}$ range & $7.3-8.9$ & $7.4-8.8$ & $6.7-8.1$ \\
\hline Conductivity range $\left(\mu \mathrm{S} \mathrm{cm}^{-1}\right)$ & $77-171$ & $46-187$ & $20-95$ \\
\hline Mean stream width (m) & $4.97 \pm 1.39$ & $4.34 \pm 2.36$ & $6.80 \pm 1.09$ \\
\hline Mean water depth $(\mathrm{cm})$ & $9.94 \pm 4.66$ & $20.02 \pm 6.46$ & $17.14 \pm 2.77$ \\
\hline Mean current velocity $\left(\mathrm{m} \mathrm{s}^{-1}\right)$ & $0.66 \pm 0.26$ & $0.59 \pm 0.27$ & $0.70 \pm 0.14$ \\
\hline \multicolumn{4}{|l|}{ Mean bottom substrate (\%) } \\
\hline Boulders (> 256 mm) & $31.47 \pm 13.82$ & $30.84 \pm 18.74$ & $48.87 \pm 12.67$ \\
\hline Cobble $(65-256 \mathrm{~mm})$ & $34.14 \pm 11.89$ & $34.68 \pm 15.17$ & $32.45 \pm 10.95$ \\
\hline Gravel $(2-65 \mathrm{~mm})$ & $15.01 \pm 6.17$ & $14.89 \pm 10.37$ & $7.69 \pm 3.04$ \\
\hline Sand $(0.1-2 \mathrm{~mm})$ & $10.60 \pm 4.23$ & $10.77 \pm 10.16$ & $3.74 \pm 3.04$ \\
\hline Silt $(<0.1 \mathrm{~mm})$ & $3.45 \pm 2.55$ & $4.41 \pm 4.54$ & $2.04 \pm 1.13$ \\
\hline Organic & $4.33 \pm 3.04$ & $4.13 \pm 3.17$ & $5.17 \pm 3.01$ \\
\hline Mean fish density (Ind. ha ${ }^{-1}$ ) & $1345.9 \pm 1322.2$ & $1901.4 \pm 989.3$ & $3862.5 \pm 1559.0$ \\
\hline Mean fish biomass $\left(\mathrm{Kg} \mathrm{ha}^{-1}\right)$ & $67.5 \pm 59.8$ & $107.8 \pm 82.8$ & $344.7 \pm 182.7$ \\
\hline Mean fish cover $(\%)$ & $15.46 \pm 8.81$ & $10.18 \pm 7.57$ & $22.47 \pm 6.52$ \\
\hline
\end{tabular}




\section{Table 2 (on next page)}

Parameter estimates from the two-group exponential model to calculate the proportion of stationary $(p)$ and mobile $(1-p)$ individuals, and mean dispersal range $(1 / \lambda)$ of brown trout population.

FLM: Flamisell, NP: Noguera Pallaresa, and NV: Noguera Vallferrera. $\lambda\left(\mathrm{m}^{-1}\right)$ is the inverse of the mean displacement range, lower values of $\lambda$ correspond to more mobile individuals. 


\begin{tabular}{llccl}
\hline Stream & $\begin{array}{c}\text { Population } \\
\text { component }\end{array}$ & $\begin{array}{c}\text { Proportion } \\
(\%)\end{array}$ & $\begin{array}{c}\text { Parameter } \\
\text { estimate }\end{array}$ & $\begin{array}{c}\text { Mean dispersal } \\
\text { range (m) }\end{array}$ \\
\hline \multirow{2}{*}{ FLM } & Stationary & 87.5 & $\lambda_{s}=0.0220145 .4$ \\
& Mobile & 12.5 & $\lambda_{m}=0.00185$ & 540.5 \\
& NP & Stationary & 85.6 & $\lambda_{s}=0.0418423 .9$ \\
& Mobile & 14.4 & $\lambda_{m}=0.00269371 .7$ \\
NV & Stationary & 71.1 & $\lambda_{s}=0.0482220 .7$ \\
& Mobile & 28.9 & $\lambda_{m}=0.00436229 .4$ \\
\hline
\end{tabular}




\section{Table 3 (on next page)}

Model averaged parameter estimates, by means of an information theoretic approach, from GLMs analysis of the influence of stream features of sampling sections on brown trout departure ratio (see text for definition).

FLM: Flamisell, NP: Noguera Pallaresa, and NV: Noguera Vallferrera. Model-averaged regression coefficients $(\beta)$ are parameter coefficients averaged by model weight $\left(w_{i}\right)$ across all candidate models ( $\triangle \mathrm{AICC}<2$ ) in which the given parameter occurs; selection probability (SP) indicates the importance of an independent variable, and parameter bias is the difference between the averaged estimates $(\beta)$ and the full model coefficients. The number $(N)$ of candidate models $(\triangle \mathrm{AICC}<2$ ) and Pearson's correlation coefficient $(r)$ between observed and model predicted values are also shown. 
1

\begin{tabular}{|c|c|c|c|c|c|c|c|c|c|c|c|c|}
\hline \multirow[t]{2}{*}{ Model parameter } & \multicolumn{3}{|c|}{$\begin{array}{c}\text { All Rivers Model } \\
\qquad N=8 ; r=0.47 \\
\end{array}$} & \multicolumn{3}{|c|}{$\begin{array}{c}\text { FLM Model } \\
N=3 ; r=0.79 \\
\end{array}$} & \multicolumn{3}{|c|}{$\begin{array}{c}\text { NP Model } \\
N=12 ; r=0.62\end{array}$} & \multicolumn{3}{|c|}{$\begin{array}{c}\text { NV Model } \\
N=5 ; r=0.72 \\
\end{array}$} \\
\hline & $\beta$ & SP & Bias & $\boldsymbol{\beta}$ & SP & Bias & $\beta$ & SP & Bias & $\beta$ & SP & Bias \\
\hline Intercept & 74.999 & & 0.237 & -73.138 & & -0.227 & 4.288 & & 4.772 & 91.815 & & 0.030 \\
\hline Mean Depth (cm) & -1.442 & 1.000 & -0.021 & -2.745 & 1.000 & -0.239 & -0.123 & 0.208 & -2.289 & 2.352 & 0.224 & 0.019 \\
\hline Fish Cover (\%) & -1.109 & 1.000 & -3.069 & -1.772 & 1.000 & 0.242 & -1.339 & 1.000 & -0.396 & -0.264 & 0.366 & -0.239 \\
\hline Fish Biomass (kg ha-1) & -0.017 & 0.623 & -0.782 & -0.097 & 1.000 & -0.515 & -0.025 & 0.148 & -3.881 & -0.038 & 1.000 & -1.123 \\
\hline Organic Substrate (\%) & 0.118 & 0.182 & -5.555 & 1.246 & 0.126 & -2.124 & 0.390 & 0.292 & -2.289 & 0.761 & 0.464 & 0.104 \\
\hline Water Velocity $\left(\mathrm{m} \mathrm{s}^{-1}\right)$ & 0.991 & 0.153 & -10.204 & -5.704 & 0.323 & 0.867 & 5.981 & 0.318 & -0.923 & -55.562 & 1.000 & -0.214 \\
\hline Fish Density (Ind ha-1) & 0.012 & 0.147 & -29.545 & \multicolumn{3}{|c|}{ Not selected } & 0.014 & 0.891 & -1.178 & \multicolumn{3}{|c|}{ Not selected } \\
\hline Substrate Coarseness & 0.305 & 0.104 & 6.702 & 46.146 & 1.000 & 0.021 & 2.951 & 0.339 & -1.425 & 4.977 & 0.212 & 0.004 \\
\hline Pre Spawn Season & -0.125 & 0.077 & 2.550 & \multicolumn{3}{|c|}{ Not selected } & -9.752 & 1.000 & 0.112 & 14.314 & 1.000 & -0.131 \\
\hline
\end{tabular}




\section{Figure 1}

Map of the study area.

(A) Location of the study streams: Noguera Pallaresa (NP), Flamisell (FLM) and Noguera

Vallferrera (NV). Location of the sampled stream reaches is highlighted with a rectangle. The photos show representative habitats in the streams sampled. (B) NP. (C) NV. (D) FLM. 


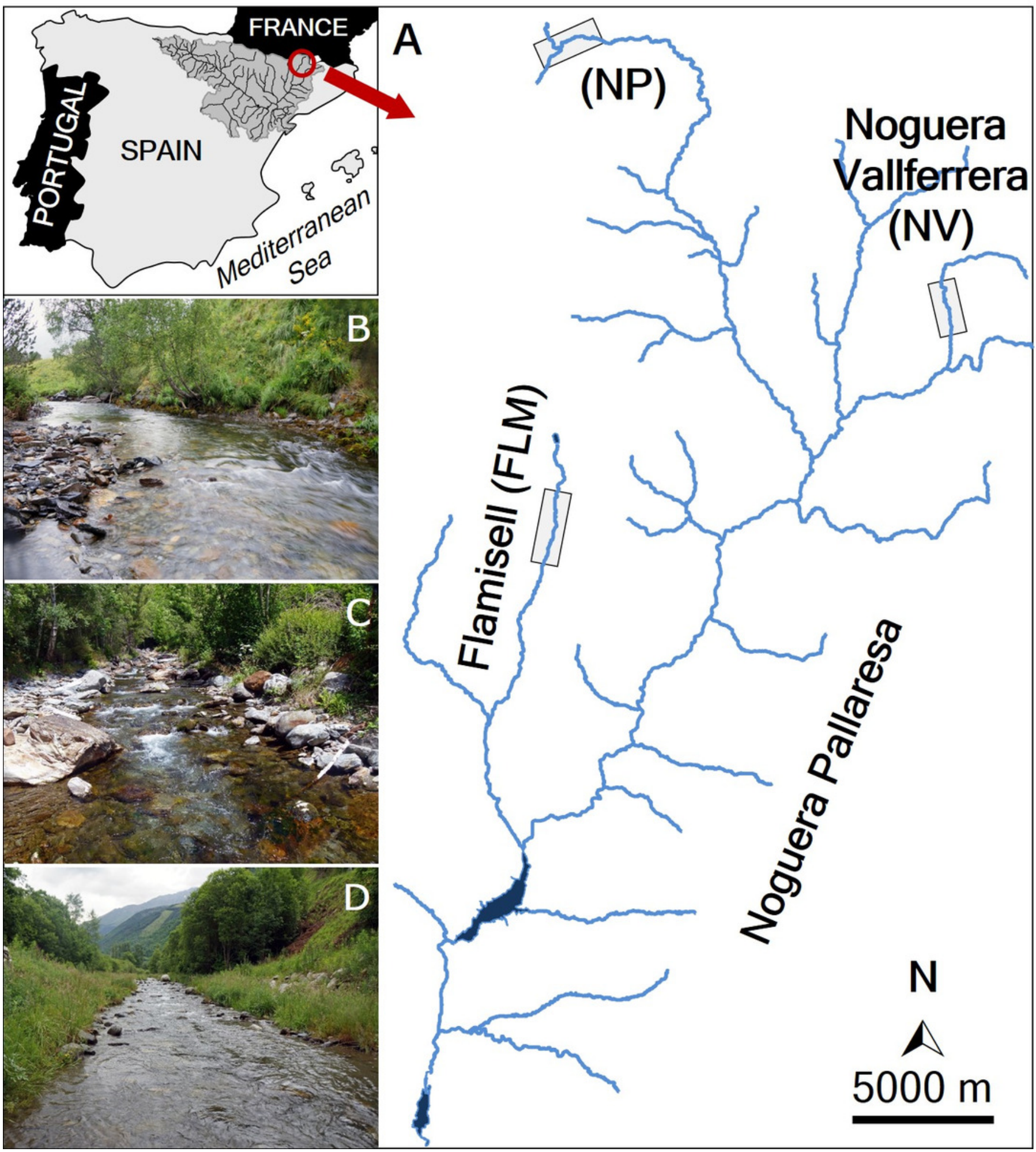


Figure 2

Evolution of the percentage of brown trout $\leq 120 \mathrm{~mm}$ fork length and $>120 \mathrm{~mm}$ fork length captured for the first time (i.e. adipose fin not clipped), on each sampling event in the study streams.

FLM: Flamisell. NP: Noguera Pallaresa. NV: Noguera Vallferrera. 


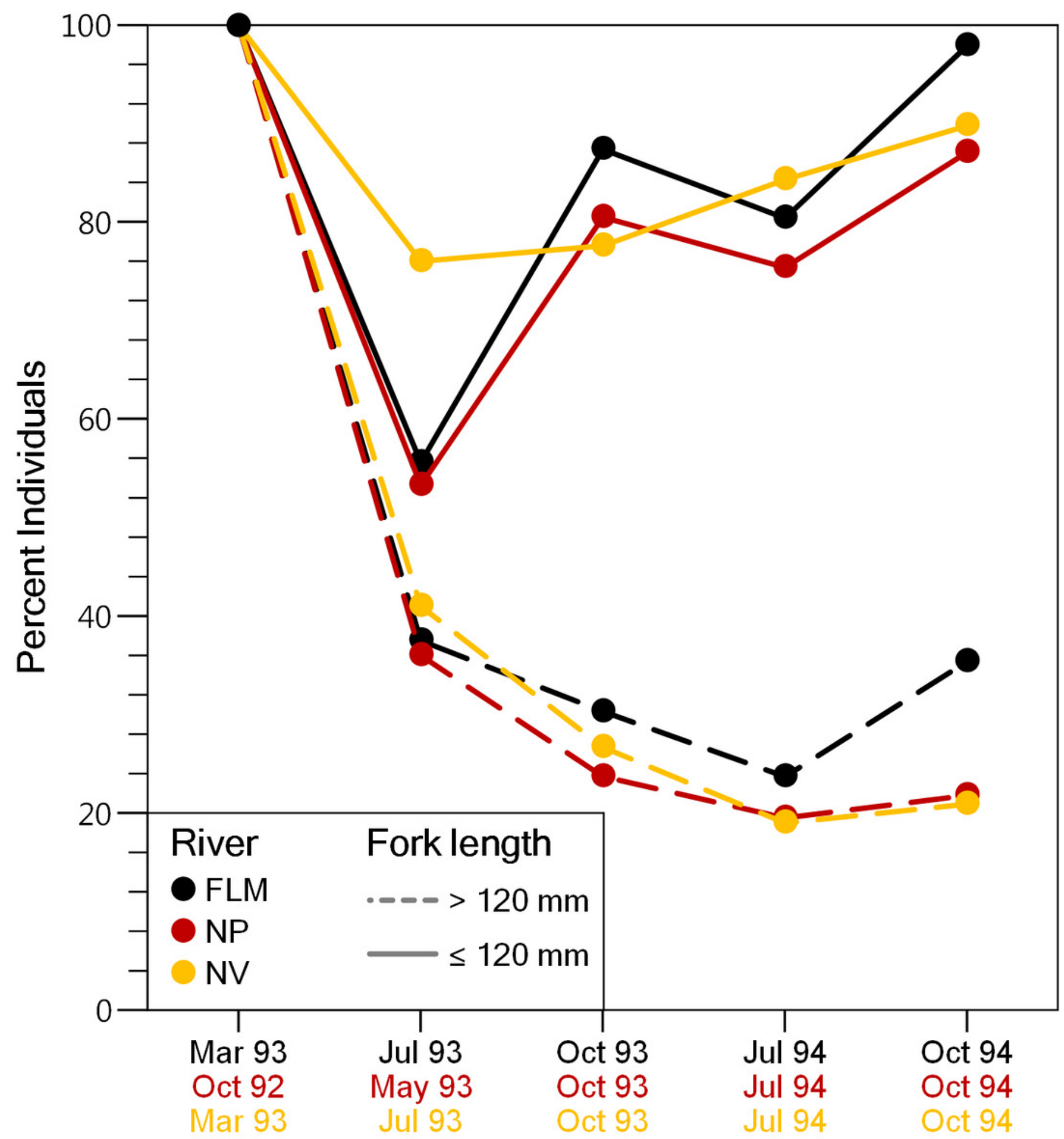

Sampling occasion 


\section{Figure 3}

Box-plot of absolute distance moved, by brown trout individuals recaptured out from home section, per sampling occasion in the study streams.

The box corresponds to the 25th and 75th percentiles, the dark line inside the box represents the median, the error bars are the confidence intervals at the $95 \%$ confidence level, and the filled circle is the mean. (A) Flamisell. (B) Noguera Pallaresa. (C) Noguera Vallferrera. 

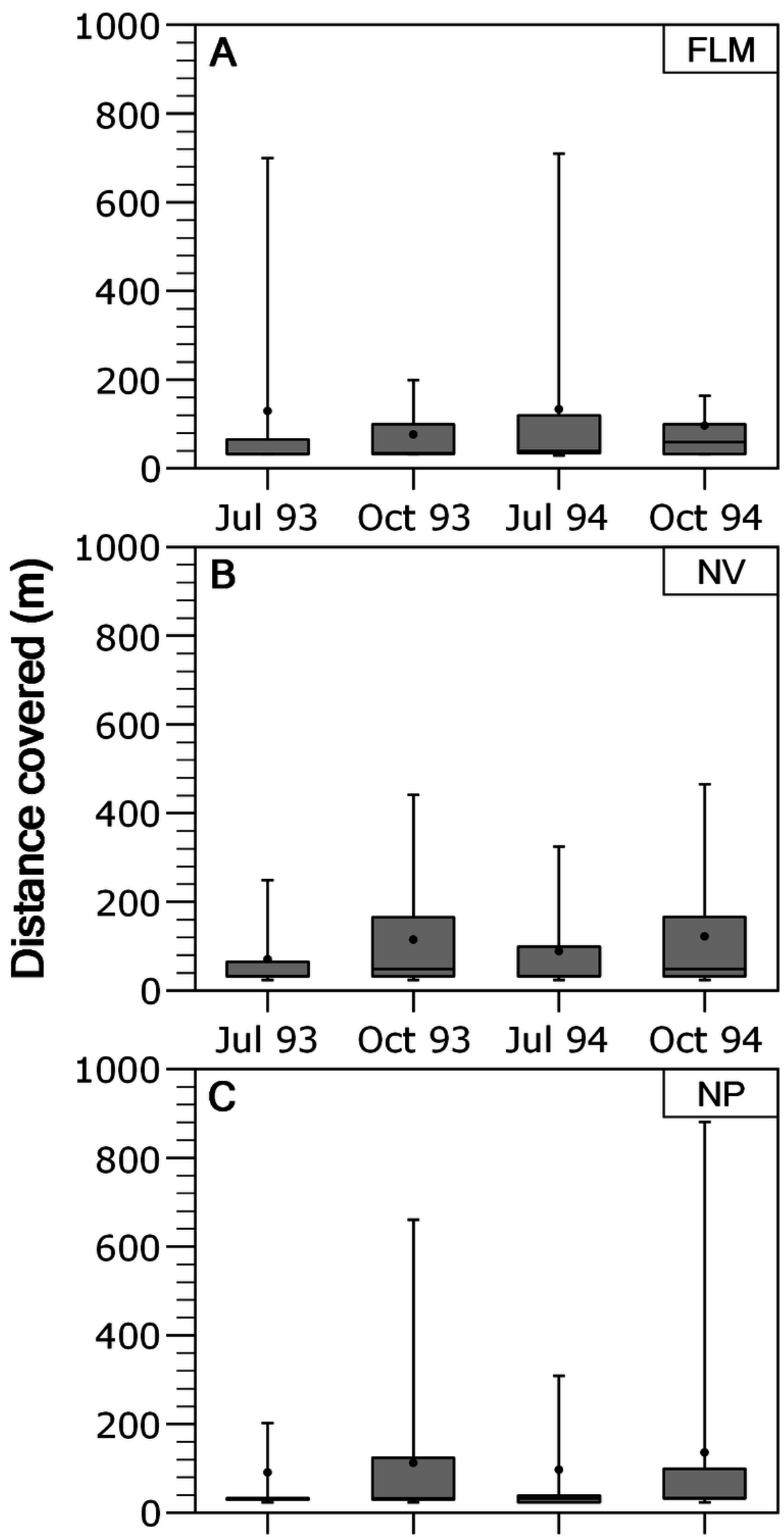

May 93 Oct 93 Jul 94 Oct 94 


\section{Figure 4}

Brown trout frequency distributions of the dispersal range fitted with a two-group exponential model in the study streams.

The solid lines are the linear regression fits for the estimated stationary (open circles) and mobile (filled circles) components of the fish populations. Distance classes are calculated from absolute values of distance moved, $y$-axis is in logarithmic scale. (A) Flamisell. (B) Noguera Pallaresa. (C) Noguera Vallferrera. 


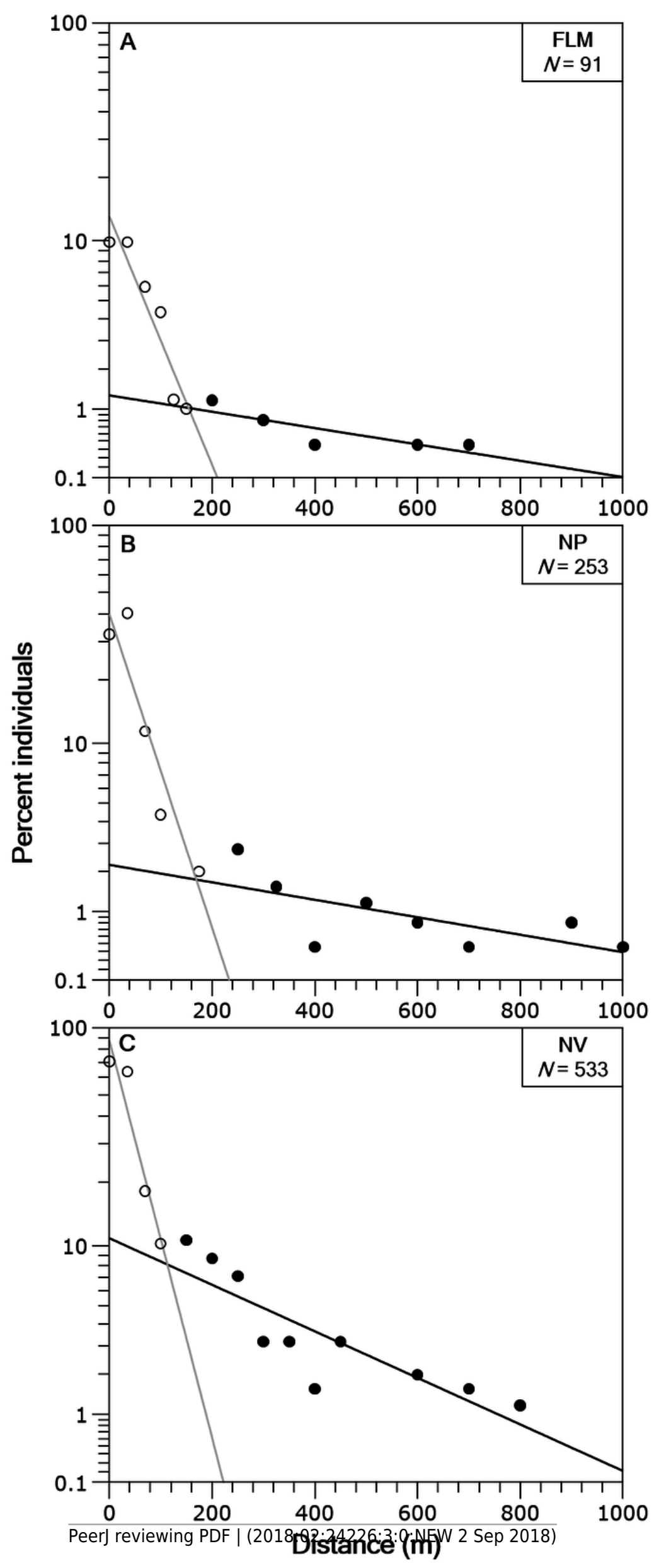

